\title{
Study on the Socioeconomic Factors Affecting Adoption of Agricultural Machinery
}

\author{
Nida Akram, Muhammad Waqar Akram, Wang Hongshu* \\ College of Economics and Management, Northeast Foresty University, Harbin, China, 150040 \\ * E-mail of the corresponding author: lwanghongshu@163.com
}

\begin{abstract}
In the context of south Asia, There is enough support for suitable agricultural machinery for small farmers. These kind of agricultural machineries can improve the return of investment in land and labor, although large capital investments are still required that can impede ownership. The growing demand for machinery has resulted in comparatively more developed rental marketplaces for irrigation, tillage and other post-harvest procedures. Numerous small businesses are therefore accepting access to farm machinery that would otherwise be incredibly expensive to buy through service fee arrangements, although there is still room for expansion. In order to facilitate the advancement and investment of such machinery more effectively, it is necessary to better understand the associated factors with the purchase of agricultural machinery and the provision of services. Firstly, current paper reviews country's policy structure which enabled the existence of such machinery markets. It then uses stratified random sample of 305 wheat producing households for the survey from six districts, identifying variables associated with the adoption of the most common smallholder agricultural machinery e irrigation pumps, threshers, and power tillers. Results of multinomial probit model show that education of farmer, member of farmer' organization, livestock ownership, farm size and being part of non-farm work activities all were significantly positive in the adoption of farm machinery. Findings also suggest that institutions and policy making authorities not only need to focus on short projects to encourage adoption of machinery, also there must be a continuous attention to improve physical and civilian infrastructure \& services, and ensuring the availability of credit to create an favorable conditions where agricultural machinery is most likely to be used.
\end{abstract}

Keywords: Agricultural machinery, Investment, Productivity, Efficiency.

DOI: $10.7176 / \mathrm{JESD} / 11-3-07$

Publication date: February $29^{\text {th }} 2020$

\section{Introduction}

The worldwide populace is predicted to the range of 9.6 billion in 2050 (Gerland et al., 2014). Accordingly, the utilization of staple food containing wheat, rice, maize, and meat items are expected to increase drastically especially in fast emerging economies (Godfray and Garnett, 2014). In order to ensure the security of cereal food only in 2050, the production demand will be more than double (Tilman et al., 2011). The current situation is complex by the predicted pressure on worldwide cultivated land accessibility; it is therefore required to strengthen the production of available land to eliminate loss of soil fertility and biodiversity (Tilman et al., 2011). These issues are very critical in extremely populated South Asian region, with per capita income below $\$ 1.25$ day_1 and the highest in extreme poverty around 399 million in 2011(World Bank, 2015b). The rural economy size is almost 3000 billion PKR within access of 22 million ha for cultivation. For rural areas, Agribusiness is the primary source of earning and employment. About 2/3 population of Pakistan belongs to rural areas with more than 110 million, About $65 \%$ of it is employed for agriculture, which is equivalent to $45 \%$ of the total employed labor (Iqbal et al., 2015). However in the meantime, increasing of rural-urban migration and development of offfarm work activities are reason of seasonal labor shortage (Zhang et al., 2014).

In this ever-changing context, there has been solid support for agricultural machineries that is suitable for farmers' small areas and resource bases, improve farm productivity, and uplift sustainable agricultural growth (FAO, 2008; Kienzle et al., 2013). Small farmers may be interested in these type of machineries because they can save production costs and reduce labor by replacing physical labor and traditional implements with them (Iqbal et al., 2015)(World Bank, 2007; Kienzle et al., 2013; Mahmud et al., 2014). These type of machines are design accordingly, to accommodate small and scattered land ownership of farmers and to encourage the agricultural resource conservation (Krupnik et al., 2013, 2015; Baudron et al., 2015). For instance, the zero or strip tillage practices need specific machinery that helps to minimize cost of production by saving time, water resources and fuel (Erenstein and Laxmi, 2008; Fileccia, 2009; Krupnik et al., 2014). In flood irrigated areas, use of laser 
levelling machine helps to save water (Ahmad et al., 2001) and Reduce groundwater reserve pressure and pumping energy savings.

However, despite the huge debate for the mechanization of agriculture, there are still questions about which factors are pertinent to the adoption and what are the implications for promoting mechanization development plans. In order to answer these questions, understanding of farm and household, who encourage to invest in agricultural machinery, including self-use and for rental services.

This thought is significant, in light of the fact that as opposed to the predominant machinery ownership pattern on large farms in developed economies, in developing economies like Pakistan relatively few farmers are interested to invest in farm machinery ownership. Rather, a large number of small farmers are getting access to agricultural machinery through customized rental services (Biggs and Justice, 2015). The study of machineryowned households can reveal the clear insight into the factors that encourage or discourage investment choices for agricultural machinery, attracting strategic planners and legislators, credit issuing authorities including domestic and foreign banks for appropriate investments. However, few studies investigate these issues. Current study will identify these factors related to the agricultural machinery adoption including tractor, thresher and irrigation pumps, using primary data from Pakistan.

There are many reasons to investigate this case. The agricultural sector accounts for 19.53\% of Pakistan's GDP and employs $43 \%$ of the workforce. The agriculture sector accounts for $19.53 \%$ of country' GDP and employs $43 \%$ of the workforce (GOP, 2017). Though, evidences show a major reduction in the availability of rural labor because they migrate to big cities and involved in non-farm work activities for higher income (M. W. Akram, N. Akram, W. Hongshu, S. Andleeb, et al., 2019; N. Akram, Akram, Wang, \& Mehmood, 2019). It can be noticed that the population is increasing, the land ratio with people is getting worse, and the demand for food is also rising (Iqbal et al., 2015). It is well-known that proficient utilization of machinery quickens the cultivation procedures and boosts other operations like harvesting and threshing.

At the meantime, there is little scope to extend the agricultural land frontier: cropland availability in South Asian countries, like Pakistan, India Bangladesh and Nepal has declined from 0.17-0.36 hectors per capita in 1961 to 0.12-0.24 hectors in 2012. Therefore, Pakistan need to improve yield per hectare. Likewise, alleviating the agricultural labor demand due to the increasingly lucrative alternate employment forms of the country (M. W. Akram, Akram, Hongshu, \& Mehmood, 2019). Suitable agricultural mechanization has been identified as a crucial development plan in Pakistan (Bochtis, Sørensen, \& Busato, 2014). Despite the impressive growth of mechanical technology, the users of tube well, tractor and thresher technologies are only about 34 percent, 38 percent and 17 percent, respectively, of the total farms. In 1994, Pakistan used only 252,861 power tillers, 454,227 pumps (containing ground, shallow and deep water pumps) and 112,707 wheat threshers (Amjad, Abbas, Ahmad, \& Ali, 2014). By the late 2010s, these numbers add up to at least 6040533 power tillers (Amjad et al., 2014), 872444 pumps (Kazmi \& Ertsen, 2011), and 0.25 million threshers. Therefore, a study of Pakistan provides vital facts on issues related to the expansion of farm implements.

Current paper will study the factors affecting the ownership of agricultural machinery in Pakistan. By using primary data of rural farm households, we distinguish that farmers who invest in farm mechanization, also evaluating the role of public and private institutions. Firstly, paper give a background of policy that encourage farm machinery development markets in Pakistan, specially focus on farm mechanization growth, liberal governmental policies regarding subsidy plans. Secondly, detailed information of methodology and econometric model. Finally, the main findings of this study are presented and important implications of farmers' owning agricultural machinery on an appropriate scale is undertaken.

\section{Agricultural mechanization in Pakistan}

Pakistan is sixth largest populous country in the world with a population of 207.77 million, and the second most populated country in South Asia (MOF, 2017-18). Wheat is one of the main staple food of Pakistan, with the $124 \mathrm{~kg}$ per capita consumption of every year. Wheat accounts for $3 / 4$ part of the daily calorie needs and is the maximum part of per capita consumption of the world (Raza, 2018). The Government of Pakistan (GOP) encourages the farm mechanization to improve per hectare yield and overwhelm food security challenges (Rahman, Hussain, \& Taqi, 2014). To promote agricultural mechanization, GOP chose to reduce the import tax and present several subsidies and credit loan programs (MOF, 2017-18). Agricultural machining was firstly introduced in Pakistan by "Esakhel Estate Farm" after the first power tiller imported in the early 1950's. Subsequently, John Deere undertook the production units of agricultural machinery and tools (UAF, 2015). Later, Rana tractors emerged and then Millat tractors introduced as leading manufacturer of agricultural machinery in 
1964 (Luqmani \& Quraeshi, 2011). That was considered as a first step on the way to farm mechanization. Due to the friendly governmental policies, The machinery manufacturing units reached 500 in 1984 (UAF, 2015). Tractor is one of the main power source of farm mechanization. Other manual power sources like animals, small tools and labor force are not efficient in modern world of farm mechanization (Iqbal et al., 2015). In the last decade of 20th century, total number of tractors in Pakistan was 300,000, until 2007 growth rate is more than double and raised to 950,000 in 2014 (MOF, 2014-15). Despite this, it's per hectare horsepower (1.5) is still lower than other countries. For instance, India (2.50), China (3.88) and Japan (7.00) even lower than international standards (Iqbal et al., 2015). On the other side, use of other implements for preparation of land, sowing/seeding, crop protection, and harvesting/threshing also become essential tools in modern farming, with a total tillage 1 area of 900,000 (MOF, 2014-15). Sowing machine is important because proper spacing and maintaining depth of each planted seed is crucial to get higher output (Tanveer, Hussain, Sohail, Kissana, \& Abbas, 2003). Different crops need different type of drills, for example, conventional tillage specially use for wheat to reduce distance and depth issues and must take time to prepare land for seed drilling (Younis, Sabir, Iqbal, \& Alit, 2006). In the past decade, the increased trend of mechanized farming is due to the awareness of agricultural machinery and farmer friendly governmental policies. According to MOF (2014-15), units of sower, tiller and harvester were $0.30,1.43$ and 0.35 million accordingly in 2014 .

Regardless of this evolution in agriculture sector, there is still need to focus on farmers by policymakers, who believe that chemical is better for higher output. One reason is may be limited purchasing power that restrict them to adopt or purchase modern technologies like tractor (ur Rehman, Khan, Tayyab, Akram, \& Faheem, 2016). Farmers often depend on cheaper domestic manufactured apparatuses, including tiller, thresher/harvester, trolley/trailer, they are not according to international standards and having shorter life span (Tahir \& Mohamed, 2015). In addition, these kinds of machines like tractor are reason of shortage of horsepower capacity (Iqbal et al., 2015). These substandard pre- and post havest machines decline the yield by $40 \%$ to $80 \%$ (Ahmad, Shah, \& Zahid, 2004). Therefore, there is an opportunity to increase production through agricultural mechanization. The above mentioned challenges need to address to strengthen the mechanization of Pakistan's agricultural sector. In addition, more insights are needed about factors related to agricultural mechanization, but it is still uncertain.

\section{Materials and methods}

\subsection{Data description}

This study uses cross-sectional data representing the rural household levels in Punjab, Pakistan. The data employed in this study was gathered from farmers living in six different districts across the province of Punjab, Pakistan using a survey method. A stratified random sample of 305 wheat producing farmers were selected for the survey. The questionnaire used in the survey was tested and validated through structured interviews conducted by domestic enumerators who were trained before practice. The data collection process took place from August to December, 2017. The six districts that constitute the sample area include Jhang, Sahiwal, Faisalabad, Sheikhupura, Khanewal and Toba Take Singh. The collected data provided information on ownership of the most common types of farm machinery, including irrigation pumps, threshers, power tillers and other farm implements. The survey also collected information on the characteristics of the both the farm and the household.

Firstly, variables at the household level include the farmer's level of education, age, and family size, as well as their ownership of livestock. Other household characteristics include the extent of a farmer's participation in non-farm activities, their affiliation with any farmers' organization, as well as the extent of his access to credit services. Farm level variables include the access to gravel or paved road, type of ownership of farm land whether it is owned or leased(includes fixed renter and shared crop), farm size (ha), alternative source of energy other than fuel (electricity or renewable energy) and agricultural labour (both employed and familial). Detailed information regarding the inputs used were also collected.

\footnotetext{
${ }^{1}$ Tillage also include the other kind of land preparing equipment, such as disc plough/hover, rotavator and moldboard plough.
} 
Table 1. Farm Machinery ownership and sample of Household Farm with their Region

\begin{tabular}{|l|l|l|l|l|l|l|l|}
\hline Description & Faisalabad & Jhang & Khanewal & Sahiwal & Sheikhupura & T.T Singh & Total \\
\hline Household farm & 50 & 49 & 69 & 44 & 44 & 49 & 305 \\
\hline No machinerya & 4 & 10 & 11 & 7 & 6 & 11 & 49 \\
\hline Tubewell/waterpumpb & 17 & 11 & 17 & 12 & 14 & 12 & 83 \\
\hline Tractorc & 7 & 11 & 7 & 6 & 7 & 7 & 45 \\
\hline Tillage/other farm implimentd & 11 & 12 & 12 & 12 & 11 & 8 & 66 \\
\hline Harvestor/Thareshere & 11 & 5 & 22 & 7 & 6 & 11 & 62 \\
\hline
\end{tabular}

a Household owns no machinery includes Irrigation pump, thresher, power tiller or other farm implements b Household owns Tube well or any type of water pump c Households owns tractor for land preparation using mechanized method $\mathrm{d}$ Household owns tillage or other farm implements using for land preparation to cultivation of crop. e Household owns any kind of thresher or harvester

\subsection{Model specification and estimation}

In order to study the determinants of Pakistani farmers' ownership of agricultural machinery, the following equation (1) was developed:

$$
Y_{l}-\alpha+\left(H H C_{l}\right) \emptyset+\alpha_{1}\left(\operatorname{Road}_{r a}\right)+\alpha_{2}\left(\text { Labor }_{\Omega}\right)+\sum_{x=1}^{2} \beta_{l}\left(R_{j}\right)+s_{1}
$$

The dependent variable is defined by Yi, zero means that the farmer does not have any farm equipment (comprising pumps, tube wells, tractors, tiller equipment, threshing and harvesting machine). If a farmer has any water pump or tubewell for irrigation, then given value was " 1 ", " 2 " if have tractor, " 3 " for having tillage related tools and for owning thresher or harvester, value was " 4 " 2 . Related to other instrumental variables, independent variable $\mathrm{HHCi}$ includes age of farmers, It is further divided into three categories: young people (35 years old or younger), middle-aged people (36-56 years old) and seniors (56 years old or older). Two categories of Education is included; no education/primary and high school/secondary. Additional household characteristics include family size of farmer, farmer is associated to farmer' organization, and having ownership of livestock considering the value 1 , if not then 0 . $\mathrm{HHCi}$ explanatory variable also includes farm size and given value is 1 if status of land ownership is fixed renter3. In the view of that, as per our model farm size be determined by the leased land area, and also investigate the effect of leased and owned land on machinery ownership. HHCi is also composed of a dummy; if the family can obtain credit from an institution or other private source, assumed value is 1 , otherwise zero. If the household able to own at least one non-engine agricultural machine by using energy sources (eg, renewable energy, electricity), then 1 dummy value is given, otherwise zero value.

Equation (1), second independent variable Roadra analyse the effect of road access; If the road is paved or gravel then assign a value 1 , otherwise zero. Lastly, in equation 1 Labor $_{z}$ used as independent variable to examine the effect of accessible labour force on the adoption of machinery.

This consists of two dummy variables, the first of which is the family labour (number of working days) and the second is hired/non familial labour (if any). Availability of labour may effect differently in the ownership of machinery. For example, demand of labour will be high if tube wells are used for irrigation during the dry season to enhance the yield and growth of crops. In contrast, other machines like power tiller thresher can decrease labour requirements. Regional setup and facilities may impact the machinery adoption and to determine that effect on agricultural mechanization, $\mathrm{Rj}$ use as independent variable. The parameter $\boldsymbol{a}_{\mathrm{c}}$ is suppose as scalar, $a, \beta$ and $\emptyset$ are vector parameters; i, ra, $\mathrm{d}$ used for household, road access, working labour (number of days) respectively and $\varepsilon$ for random error.

Tube-wells or irrigation pumps are most common machines owned by farmers, but farmers can also have other

\footnotetext{
${ }^{2}$ We follow the rule of basic need while coding of the machinery, e.g. water is basic factor for agriculture, after that tractor is the basic source of power for tillage and harvesters in our study area without tractor can't use other two type of machinery and later tillage and harvester. According to machinery type and need the coding supposed to overrule the pervious machinery, tractor overruled the tube well and tillage overrule the ownership of tractor, same as thrasher overrule the all other types of machinery, it's mean farmer have all type of machinery (Table 1) (Mottaleb, Krupnik, \& Erenstein, 2016)

${ }^{3}$ The research area have two kind of lease agreements (Fixed rent and share cropper), we considered the two categories into one as land own by farmer or not.
} 
agricultural machinery (Table 1). Therefore, current paper use multinomial probit model that is extensively used to express the use of more than one machines; Mottaleb, Mohanty, and Nelson (2015) use this model to investigate the "determinants for hybrid rice adoption for Bangladesh". Quayum and Ali (2012) also used a single logit estimation regarding the adoption of power tillers.

Four models are then evaluated to measure the impact of these factors on the adoption of agricultural machinery by farmers, and to control possible endogenous problems within the data set. First, we include all the aforementioned explanatory factors for the unlimited full model. Three other limited models (L1-L3) have also been calculated. For the isolation of the concerned explanatory variables, exclude the specified factors to avoid possibility of endogeneity and other abbreviation related issues. For instance, the farm size was counted in the unrestricted model and it can be considered that adding of related dummy variables such as farm ownership status (owned and leased) may be redundant. Therefore, we omitted farm size and variables related ownership status in R1. In R2, we omitted farm size and related variables along with ownership of livestock.

These factors were excluded because it possible for a farmer to initially invest in mechanised farming equipment for their farm and purchase a machine before using the same machine to offer or provide services to other farmers in exchange for money. Additional investments in such resources, such as that of land or livestock, may occur. The credit facility was excluded from the L3 model because such credit could be obtained based on physical capital available through collateral.

\section{Results and discussion}

\subsection{General survey results}

The current study's survey specification can been seen in table 2. Data showed that livestock ownership in targeted sample district wise area is 74\% in Faisalabad, 79\% in Jhang, 56\% in Khanewal, 68\% in Sahiwal, 50\% in Sheikhupura and 85 in Toba Tak Singh. Data showed that $27.5 \%$ of the sampled farm households owned water pump, $16.4 \%$ owned tractor, $21.6 \%$ owned tillage or other farm implements, and $18.4 \%$ owned thresher or harvester. Households are more likely to own tube well or water pump compared other types of machinery. Water is the basic need of agriculture and due to the ground water scarcity majority of farmers own tube well or any type of water pump to extract ground water. On average, nearly $35 \%$ of the sampled households operated at least one agricultural machine using electricity, primarily for irrigation pumps that require connections for deep pumping, and to a lesser extent for shallow tube well extraction. Statistics revealed that on average more than $50 \%$ of the sampled households can received loans or credit services from banks or other informal sources. On average, $73.8 \%$ household have access to paved or gravel roads.

Table 2. Households sample's resource endowments by region

\begin{tabular}{|c|c|c|c|c|c|c|c|}
\hline & \multicolumn{6}{|c|}{ Region wise sample } & \\
\hline Description & Faisalabad & Jhang & Khanewal & Sahiwal & Sheikhupura & T.T singh & Total \\
\hline Livestock & 74 & 79 & 56 & 68 & 50 & 85 & 68.5 \\
\hline Credit access & 52 & 55 & 51 & 73 & 39 & 51 & 53.1 \\
\hline source of power & 34 & 37 & 42 & 34 & 30 & 29 & 34.8 \\
\hline owned land & 76 & 67 & 68 & 68 & 55 & 53 & 64.9 \\
\hline leased land & 70 & 57 & 59 & 75 & 79 & 67 & 67.2 \\
\hline Road access & 88 & 67 & 68 & 81 & 75 & 65 & 73.8 \\
\hline Tubewell/waterpump & 34 & 22 & 25 & 27 & 34 & 25 & 27.5 \\
\hline Tractor & 14 & 23 & 10 & 14 & 27 & 14 & 16.4 \\
\hline $\begin{array}{l}\text { Tillage/other farm } \\
\text { impliment }\end{array}$ & 22 & 24 & 17 & 27 & 25 & 16 & 21.6 \\
\hline Harvestor/Tharesher & 22 & 10 & 31 & 16 & 14 & 23 & 18.4 \\
\hline
\end{tabular}

Civil infrastructure (roads \& electricity power grids) as well as institutional infrastructure (loan facilities) may affect the availability of agricultural machinery and farmers' investment decisions, overall affecting operating 
and transaction cost of the sellers and buyers of the machine. The availability of electricity could encourage farmer to buy an irrigation pump, since the availability of a subsidized electric driven tubewell program offer an economical source of energy.Diesel pumps also require pre-season fuel precuement and require transportation costs from the point of purchase to the pumping station. Likewise, access to available loans facilities could influence investment decisions in agricultural machinery, particularly for expensive machines like tractor Thresher and harvester. Our study sample comprised $64.9 \%$ of owned farm land and $67.2 \%$ leased land 4 , where in later includes both rent and share cropper tenants.

Table 3. Multinomial Probit model to evaluate the farm machinery ownership

\begin{tabular}{|c|c|c|c|c|}
\hline Model Specifications & \multicolumn{4}{|c|}{ Unrestricted Model } \\
\hline Variables & Tubewell/waterpump & Tractor & farm implements & Harvestor/thresher \\
\hline \multirow[t]{2}{*}{ Age } & $-0.963 * * *$ & $-1.163 * * *$ & $-1.127 * * *$ & $-1.058 * * *$ \\
\hline & $(0.317)$ & $(0.338)$ & $(0.349)$ & $(0.390)$ \\
\hline \multirow[t]{2}{*}{ Education } & $0.577 * *$ & $0.7588 * *$ & $1.399 * * *$ & $1.979 * * *$ \\
\hline & $(0.291)$ & $(0.313)$ & $(0.328)$ & $(0.359)$ \\
\hline \multirow[t]{2}{*}{ Household size } & $-0.306^{* * *}$ & $-0.409 * * *$ & $-0.469 * * *$ & $-0.644 * * *$ \\
\hline & $(0.088)$ & $(0.105)$ & $(0.114)$ & $(0.145)$ \\
\hline \multirow[t]{2}{*}{ Farmer' organization } & $1.1601 * * *$ & $1.474 * * *$ & $2.026 * * *$ & $2.821 * * *$ \\
\hline & $(0.419)$ & $(0.454)$ & $(0.484)$ & $(0.572)$ \\
\hline \multirow[t]{2}{*}{ Livestock ownership } & $0.701 *$ & $0.844 * *$ & $1.195 * *$ & $1.518 * *$ \\
\hline & $(0.391)$ & $(0.438)$ & $(0.478)$ & $(0.591)$ \\
\hline \multirow[t]{2}{*}{ Farm size(ha) } & 0.119 & $0.24 * *$ & $0.378 * * *$ & $0.514 * * *$ \\
\hline & $(0.093)$ & $(0.098)$ & $(0.104)$ & $(0.118)$ \\
\hline \multirow[t]{2}{*}{ Credit access } & $0.678^{*}$ & $0.854^{*}$ & 0.736 & $1.1907 * *$ \\
\hline & $(0.419)$ & $(0.451)$ & $(0.475)$ & $(0.559)$ \\
\hline \multirow[t]{2}{*}{ Power source } & 0.866 & 1.203 & 1.353 & 1.407 \\
\hline & $(0.445)$ & $(0.483)$ & $(0.506)$ & $(0.574)$ \\
\hline \multirow[t]{2}{*}{ Road access } & 0.223 & 0.433 & $1.009 * *$ & $1.6702 * * *$ \\
\hline & $(0.3901)$ & $(0.434)$ & $(0.478)$ & $(0.629)$ \\
\hline \multirow[t]{2}{*}{ Hired labor } & -0.019 & $-0.052 * *$ & $-0.117 * * *$ & $-0.231 * * *$ \\
\hline & $(0.015)$ & $(0.021)$ & $(0.029)$ & $(0.045)$ \\
\hline \multirow[t]{2}{*}{ Family labor } & -0.001 & -0.025 & $-0.075 * * *$ & $-0.151 * * *$ \\
\hline & $(0.016)$ & $(0.018)$ & $(0.024)$ & $(0.035)$ \\
\hline \multirow[t]{2}{*}{ Non-farm work } & 0.284 & 0.328 & 0.575 & $1.252 * *$ \\
\hline & $(0.391)$ & $(0.425)$ & $(0.450)$ & $(0.549)$ \\
\hline \multirow[t]{2}{*}{ Owned land } & 0.251 & 0.385 & 0.833 & $1.232 *$ \\
\hline & $(0.445)$ & $(0.493)$ & $(0.521)$ & $(0.628)$ \\
\hline
\end{tabular}

\footnotetext{
${ }^{4}$ Due to the uneven distribution of agricultural land in Pakistan, it is usual practice to lease land from farmers who have excess land. There are two kinds of lease arrangements; fixed renter (land owner and tenant agree on a fixed amount of rent to be paid for land) and share cropper (tenant and land owner share the crop yield) (Ali, Abdulai, \& Goetz, 2012). Some farmers may have mixed land ownership status. For example, a farmers have own land and also get some land on lease.
} 


\begin{tabular}{|c|c|c|c|c|}
\hline Leased land & 0.276 & 0.084 & 0.565 & $1.158^{*}$ \\
\hline & $(0.512)$ & $(0.542)$ & $(0.569)$ & $(0.648)$ \\
\hline District & $-0.04001^{* *}$ & $-0.026^{* *}$ & $-0.083^{* *}$ & $-0.077^{* *}$ \\
\hline Constant & $(0.112)$ & $(0.125)$ & $(0.132)$ & $(0.154)$ \\
\hline No. of observations & $1.818^{*}$ & 1.831 & 0.684 & $(1.766)$ \\
\hline Wald Chi2 (60) & $(1.143)$ & $(1.301)$ & $(1.432)$ & 305 \\
\hline Log likelihood ratio & & 129.27 & \\
\hline Prob>chi2 & \multicolumn{3}{|c|}{-299.65} \\
\hline
\end{tabular}

Robust standard error are in () and significance level at $10 \%, 5 \%$ and $1 \%$ shows as $* * *$ and $* * *$ respectively

\subsection{Estimated unrestricted functions}

All possible household and farm level explanatory variables are include in unrestricted model, with the $1 \%, 5 \%$ and $10 \%$ significance level, and the coefficient signs explain tube well/water pump, tractor, thresher/harvester and other farm implements ownership in table 3. Household and farm level variables such as Education of farmer, member of farmer' organization, livestock ownership and being part of non farm work activities all were significantly positive in the adoption of farm machinery at the level of $1 \%, 5 \%$ and $10 \%$ differently. Conversely, variables include age of farmer, household size, hired or out sourced labor and family labor were negatively significant with machinery adoption at $1 \%$ to $10 \%$ differently. Moreover, Farm size was also have statistically positive correlation with all kinds of machinery adoption $(\mathrm{p}<0.05$ to 0.10$)$ but not significant in case of tube well/water pump. While the farm land ownership status (owned and leased) was found to have a positive impact on machinery adoption but only significant for thresher/harvester ( $<0.05$ to 0.10 ). Results revealed that accessibility to road was positive for all kinds of machinery adoption, while only significant at $5 \%$ and $1 \%$ for farm implements and thresher/harvester, respectively. Further, source of power energy (like renewable energy and electricity) were found to have a positive relationship with all kinds of machinery adoption but statistically is not significant. However, the influence of credit facility access was found $5 \%$ to $10 \%$ significant for machinery adoption with the exception of farm implements.

\subsection{Estimated restricted model}

The first restricted model, R1 excludes the explanatory variables, which concerns to farm size, access to gravel or paved road and farm owner ship status whether owned and leased. In second restricted model R2, excludes livestock ownership and related variables exclude in first model except road access. In third restricted model R3, excludes related variables of second model and possible external source of funding variables such as credit access, nonfarm work. In first and second restricted model, External financing variables credit access and off farm work, source of power (electricity or other renewable energy) and infrastructural variable (road access) all are positively significant at the level of $1 \%$ to $10 \%$ differently in table 4 .

Therefore, the estimation of restricted models (R1) and (R2) show that variables related to external financing, infrastructure and energy source have positive relationship with adoption of machinery and does not have any bias compared to machinery ownership, which are mainly linked with land ownership status and farm size. In third model (R3), in addition to excluding any possible outstanding endogenous factor, we also exclude non farm work, credit access, livestock, farm size and other farm status related variables. Similarly to the predicted function in the R1, R2 and R3 model, after statistically regression analysis, the effect of alternative power source and road access on the ownership of farm machinery, revealed themselves to be significant at $1 \%$ to $10 \%$ differently. The household characteristics age, education, household size and part of farmer' organization all are significant in three restricted models (Table 4) and unrestricted (Table 3) prove that there is no endogeneity effect. We have found that regional variable in all restricted and unrestricted model is significant at $5 \%$, that means the infrastructure and information flow is very important for farm mechanization.

To verify the predicted model, we performed a post estimation' log likelihood ratio test by placing all restricted models within an unrestricted model. The likelihood ratio for restricted model R1 was 48.48, R2 48.24 and R3 66.46 , and all ratios are found to be significant at $1 \%$ level. Overall, Table 4 emphasis that the unrestricted model 
is more satisfactory when estimating machinery ownership and adoption.

\begin{tabular}{|c|c|c|c|c|c|c|c|c|c|c|c|c|c|c|c|c|c|c|c|}
\hline 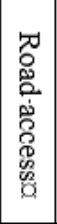 & $a$ & 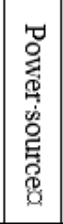 & $\not$ & 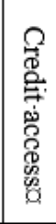 & $a$ & 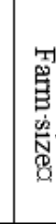 & 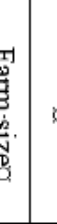 & $q$ & 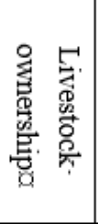 & $\not$ & 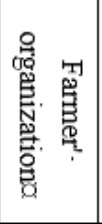 & 0 & 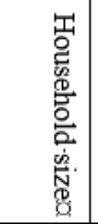 & o & \begin{tabular}{|c|} 
펄 \\
: \\
总 \\
: \\
: \\
\end{tabular} & $\not$ & 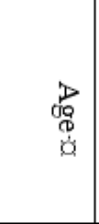 & $\not$ & 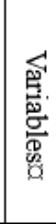 \\
\hline d & 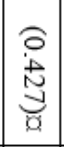 & \begin{tabular}{|l|}
0 \\
0 \\
0 \\
0 \\
0 \\
0 \\
0 \\
\end{tabular} & $\begin{array}{l}\text { ô } \\
\text { i } \\
0 \\
0 \\
0 \\
0\end{array}$ & $\begin{array}{l}0 \\
0 \\
\infty \\
o \\
o \\
0 \\
0\end{array}$ & $q$ & q & 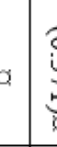 & 㴔 & $\begin{array}{l}\circ \\
\dot{\leftrightarrow} \\
\stackrel{\vec{a}}{a}\end{array}$ & 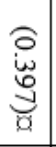 & 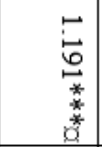 & $\begin{array}{l}0 \\
0 \\
0 \\
0 \\
0 \\
0 \\
0 \\
\end{array}$ & 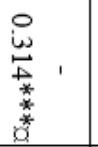 & 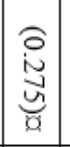 & 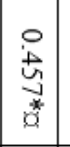 & $\begin{array}{l}\text { Oे } \\
\stackrel{N}{0} \\
\stackrel{0}{0} \\
\end{array}$ & $\begin{array}{l}0 \\
0 \\
0 \\
0 \\
* \\
0 \\
0\end{array}$ & 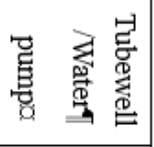 & \multirow{4}{*}{ 客 } \\
\hline$a$ & 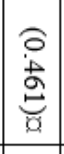 & $\begin{array}{l}\vec{w} \\
\mathbf{y} \\
* \\
\frac{*}{*} \\
0\end{array}$ & 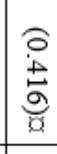 & 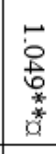 & $\not$ & p & 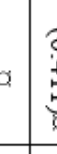 & 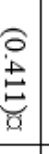 & 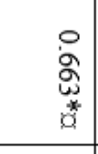 & 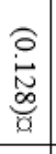 & 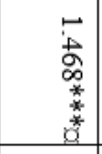 & $\begin{array}{l}0 \\
0 \\
0 \\
0 \\
0 \\
0\end{array}$ & 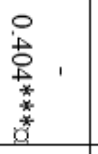 & $\begin{array}{l}0 \\
0 \\
0 \\
0 \\
0 \\
0\end{array}$ & $\begin{array}{l}0 \\
0 \\
0 \\
0 \\
0 \\
0 \\
0\end{array}$ & 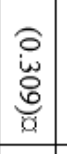 & 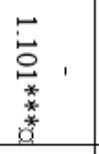 & 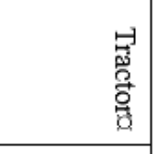 & \\
\hline$Q$ & 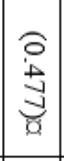 & 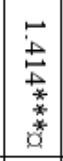 & 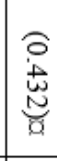 & 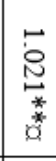 & 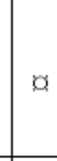 & p & 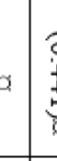 & $\begin{array}{l}\text { ô } \\
\text { 葛 }\end{array}$ & $\begin{array}{l}8 \\
8 \\
+ \\
+ \\
* \\
0\end{array}$ & 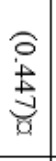 & $\begin{array}{r}\vec{b} \\
\vec{w} \\
\vec{w} \\
\vec{*} \\
0\end{array}$ & $\begin{array}{c}0 \\
0 \\
0 \\
0 \\
0 \\
0\end{array}$ & 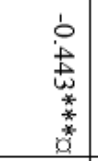 & $\begin{array}{l}0 \\
0 \\
0 \\
0 \\
0 \\
0 \\
\end{array}$ & \begin{tabular}{|c|}
$\overrightarrow{0}$ \\
0 \\
0 \\
0 \\
0 \\
0 \\
0 \\
\end{tabular} & $\begin{array}{l}\text { ô } \\
\dot{\omega} \\
\stackrel{0}{0} \\
0\end{array}$ & 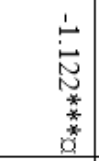 & 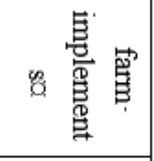 & \\
\hline$a$ & $\begin{array}{l}\text { Oे } \\
\dot{u} \\
\stackrel{0}{0} \\
0\end{array}$ & 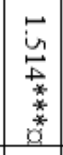 & 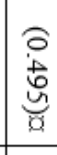 & 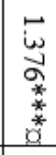 & o & a & 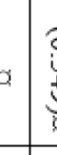 & 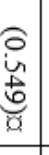 & 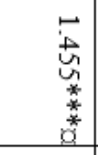 & 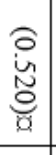 & 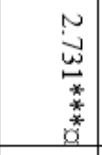 & 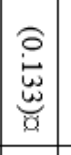 & 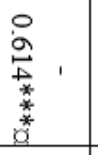 & 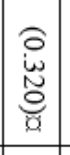 & 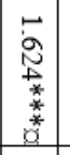 & 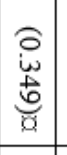 & 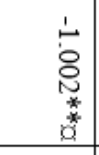 & 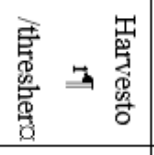 & \\
\hline $\begin{array}{l}\circ \\
\stackrel{\circ}{\circ} \\
\stackrel{\leftrightarrow}{g}\end{array}$ & 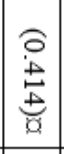 & 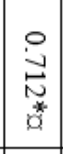 & 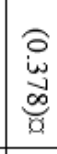 & \begin{tabular}{|l}
0 \\
0 \\
0 \\
0 \\
* \\
0
\end{tabular} & q & 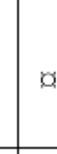 & $\alpha$ & q & $q$ & 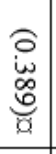 & 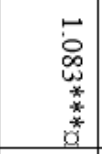 & \begin{tabular}{|l|}
0 \\
0 \\
0 \\
0 \\
0 \\
0 \\
0
\end{tabular} & 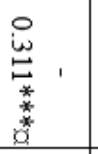 & 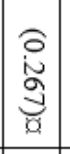 & 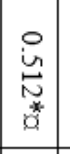 & 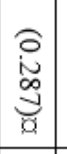 & $\begin{array}{l}0 \\
0 \\
0 \\
\infty \\
0 \\
0 \\
\vdots \\
\vdots \\
0 \\
\end{array}$ & 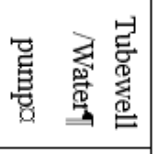 & \multirow{4}{*}{ 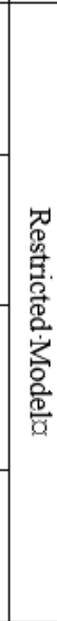 } \\
\hline $\begin{array}{l}. \\
\vec{\Xi} \\
w \\
0 \\
0\end{array}$ & 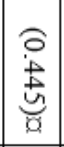 & 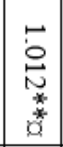 & $\begin{array}{l}0 \\
0 \\
0 \\
0 \\
0 \\
0\end{array}$ & 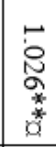 & q & $a$ & $\alpha$ & $\not$ & $a$ & 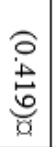 & 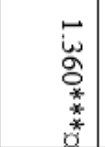 & $\mid \begin{array}{l}2 \\
\dot{0} \\
0 \\
0 \\
0 \\
0\end{array}$ & & 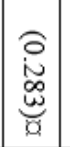 & 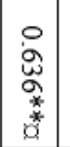 & 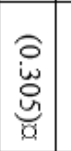 & 容 & 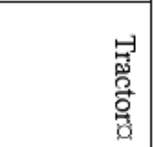 & \\
\hline 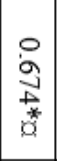 & 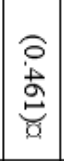 & $\begin{array}{c}5 \\
\vdots \\
\vdots \\
\vdots \\
\vdots \\
0\end{array}$ & \begin{tabular}{l} 
Oे \\
志 \\
\multirow{\sigma}{\sigma}{}
\end{tabular} & $\begin{array}{l}0 \\
0 \\
0 \\
0 \\
0 \\
0 \\
0\end{array}$ & a & 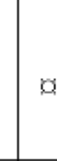 & $\alpha$ & 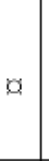 & $\not$ & $\begin{array}{l}\text { Oे } \\
\text { 岕 } \\
\stackrel{0}{0}\end{array}$ & 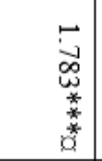 & $\begin{array}{l}0 \\
0 \\
0 \\
0 \\
0 \\
0\end{array}$ & 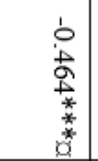 & 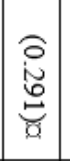 & 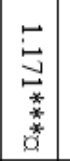 & 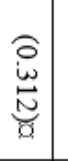 & 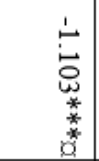 & \% 蛋 & \\
\hline 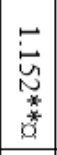 & 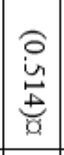 & 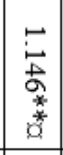 & $\begin{array}{l}0 \\
0 \\
+ \\
0 \\
0 \\
0\end{array}$ & 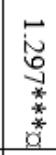 & a & $a$ & $\alpha$ & $a$ & $a$ & 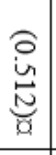 & 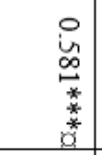 & 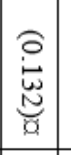 & 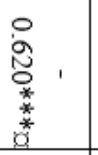 & $\begin{array}{l}\text { Oे } \\
\text { W. } \\
\stackrel{\vec{E}}{0} \\
\end{array}$ & \begin{tabular}{|c|} 
\\
0 \\
0 \\
$\vdots$ \\
$z$ \\
0 \\
0 \\
0
\end{tabular} & 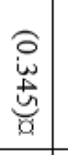 & $\begin{array}{l}8 \\
0 \\
0 \\
0 \\
0 \\
0 \\
0 \\
\end{array}$ & 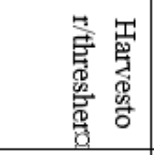 & \\
\hline 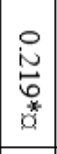 & 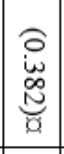 & 号 & $a$ & $\not$ & $\not$ & $a$ & $\alpha$ & $\alpha$ & $a$ & 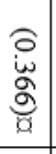 & 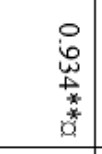 & \begin{tabular}{|c|}
0 \\
0 \\
0 \\
0 \\
0 \\
0 \\
\end{tabular} & 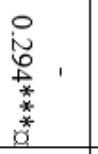 & 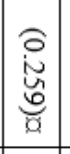 & \begin{tabular}{|l|} 
\\
0 \\
0 \\
0 \\
+ \\
0 \\
0 \\
0 \\
\end{tabular} & 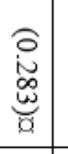 & 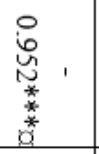 & 营 总兽 & \multirow{4}{*}{ 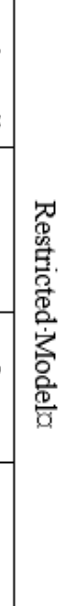 } \\
\hline 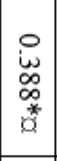 & 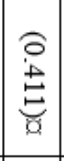 & $\begin{array}{l}\text { 음 } \\
\text { : } \\
\text { : }\end{array}$ & $a$ & $a$ & $\not$ & b & & q & $a$ & 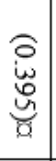 & 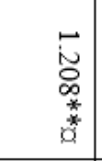 & $\mid \begin{array}{c}0 \\
0 \\
0 \\
0 \\
0 \\
0\end{array}$ & 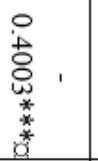 & 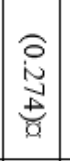 & \begin{tabular}{|c|} 
\\
0 \\
0 \\
0 \\
$*$ \\
0 \\
0 \\
0
\end{tabular} & 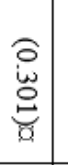 & 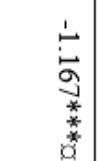 & $\begin{array}{l}\overrightarrow{9} \\
\text { 总 } \\
0 \\
0 \\
0\end{array}$ & \\
\hline $\begin{array}{c}0 \\
\infty \\
\infty \\
0 \\
* \\
0 \\
0 \\
\end{array}$ & 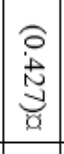 & \begin{tabular}{l}
. \\
$\dot{a}$ \\
\multirow{2}{*}{} \\
*
\end{tabular} & q & 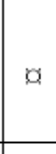 & $a$ & lo & & $a$ & $a$ & 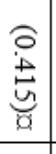 & 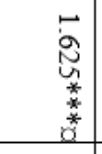 & \begin{tabular}{|c|}
0 \\
$\dot{0}$ \\
$\overline{8}$ \\
0 \\
\end{tabular} & 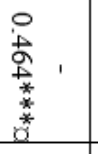 & 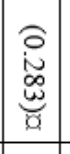 & 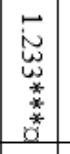 & 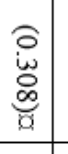 & 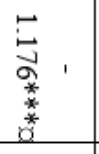 & 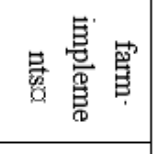 & \\
\hline 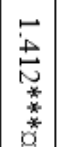 & 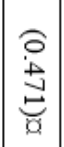 & $\mid$\begin{tabular}{l|}
0 \\
0 \\
0 \\
0 \\
+ \\
0 \\
0 \\
0
\end{tabular} & a & $a$ & 0 & o & & $\not$ & $a$ & 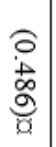 & 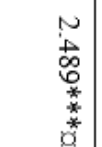 & 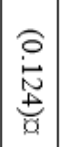 & 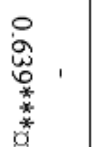 & 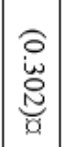 & 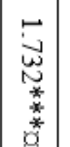 & $\begin{array}{l}\hat{\partial} \\
\dot{w} \\
\stackrel{w}{0} \\
0\end{array}$ & 富 & 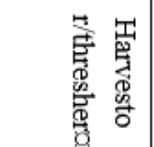 & \\
\hline
\end{tabular}




\section{Discussion}

Arranging rented services and charge-to-utilize models are two practical ways to expand access to agricultural machinery to farmers with insufficient resources. Understanding and support from the policymakers on this matter are imperative for the expansion of various suitable agricultural machinery to farmers in needs in developing countries, specifically in South Asia. Very few empirical studies of this region raise this issue and their results are not satisfactory. Furthermore, not all studies included variables on household attributes, socioeconomic factors, or infrastructural factors associated with the ownership of farming machinery. In contrast, this study covered an extensive range of variables among the final 305 observations. By reviewing the brief chronological development of the relevant agricultural policies in Pakistan, the advancement of the farm mechanization and the farm mechanization sector have always been given the top priority. Therefore, the information from this study would be an enormous step towards filling the gap in the literature and knowledge in the field. Our study highlighted the critical factors that influenced the ownership of the most basic agricultural machinery in Pakistan, including tube well/pump, tractor, thrasher/harvester and other farm implements.

The general outcomes from this study showed that farmers face difficulties to get credit facility through formal channels. The reason for this low percentage of credit access can be attributed to a lack of governmental support. Most farmers still depend on their personal capital and resources for funding of their farming practices. Kaleem and Abdul Wajid (2009) mentioned that most farmers who are given financial advances by middlemen or agents are consequently obligated to sell their crops to the same agent or middlemen at a price that is lower than the market price. The same study also stated that only $10 \%$ of all transactions were performed using cash and that people avoided banks or institutions due to complex documentation process and high transaction cost.

The study found that civilian infrastructure, especially regarding a farm's access to roads and the availability of other sources of power (electricity or renewable energy sources) are correlated with the possession of farming machinery of all kinds at the household level. However, the relationship between tube-well/irrigation pump ownership and road access were not significant. This may be because tube-wells do not need to be transported from one location to another but are fixed in a single place for irrigation of canals and fields. In contrast, road networks were found to be a significant factor for tractor ownership. Road access enables farmers to transport their harvesting surpluses to markets and thus increase their income. Apart from that, paved roads are needed for farmers to transport machinery such as thrasher/harvester from one location to another.

Moreover, infrastructure was considerably good in our study area as the selected areas are located in central Punjab. This area connects the south Punjab and Sindh provinces to the country's main power centers; here, the necessary infrastructure and road accessibility in this area are quite better. Furthermore, the China Pakistan Economic Corridor (CPEC) project initiated by China has also resulted in an improvement of infrastructures all over the country through the construction of motorways and the development of communication projects (MOP, 2017). The use of alternative sources of power, such as renewable energy, is not widely practiced in this region. The agricultural sector still depends heavily on oil usage, which increases the cost of input and subsequently influences the economic sustainability of organic farming. The use of electricity as a source of power in the agriculture sector is also low in Pakistan compared to other countries in the region, due to the severe shortage of electricity in the country. Pakistan is ranked 37th globally in terms of energy consumption. This is equivalent to as low as $43 \mathrm{~W}$ per person, which is just $1 / 7$ of the average global energy consumption (Farooqui, 2014). The government needs to put in more effort to improve farm technology by promoting the use of renewable sources in order to decrease the input cost, which can threaten the sustainability of small farms.

Water is a basic necessity for agriculture and Pakistan is highly dependent upon the Indus Basin Irrigation System (IBIS), which was designed a century ago to improve water source for human settlements and agriculture (Jurriëns, Mollinga, \& Wester, 1996). In the last few decades, the availability of water from the IBIS has rapidly decreased. Only $10 \%$ of all water requirements for agriculture as a whole in Pakistan is dependent on groundwater, but the opposite is true in Punjab in which $90 \%$ of the agricultural lands were irrigated with the groundwater via tube wells or other types of pumps (Qureshi, McCornick, Sarwar, \& Sharma, 2010). This finding was similar to our study in which most of the farmers depended on groundwater for irrigation, and most of them own their tube wells to meet their water requirements. That is the reason, in our study area tube well is the top priority machinery, and the other kinds of machinery were given lower priority based on the farmers' particular demands and needs (Table 2).

The results from the unrestricted model indicated that specific household characteristics played a more prominent role in the adoption of farm machinery, especially education of farmer. More educated farmers are 
more likely to adopt machinery. Similar findings are reported by M. W. Akram, N. Akram, W. Hongshu, and A. Mehmood (2019) and Mottaleb, Rahut, Ali, Gérard, and Erenstein (2017), indicating that education help farmers to get information from organization and encourage them to take calculated risk related agricultural machinery investment. Coefficient of age is negatively correlated with machinery adoption,

Similar findings were reported in a study by Paustian and Theuvsen (2017) younger farmers are more likely to adopt machinery. Likewise, Daberkow and McBride (2003) found that increasing age reduces the likelihood of new technology adoption. Furthermore, it was shown from our study that if a farmer had a business or another job besides farming, their financial position would be much better than those who solely depended upon the farming income. On a similar note, if the size of the farmer's household is small, then the familial labor is likely to be insufficient to run the farm optimally. Hence, this might motivate the farmers to mechanize their farming techniques. Findings from this study concerning household characteristics and the adoption of farming machinery supported this argument. These findings are also in concordance with the adoption of small-scale machinery in Bangladesh as seen in the study by Mottaleb et al. (2016) and the adoption of modern technology in the rice farms in the Philippines (Mariano, Villano, \& Fleming, 2012).

The financial position and the land size of the farmers were positively and significantly correlated to their ownership of agricultural machinery. The study found that farmers who owned more farmland and livestock were more likely to possess their own farm machinery. This is not surprising as strong ownership of capital base assets would be a good reflection of the total resources available to the farmers. However, the other side of the outcome is more interesting; the likelihood of owning farming machinery was found to be higher among farmers who owned their land rather than those who leased their land. In addition, larger farms holdings appeared to have a greater capacity to support machinery ownership, instead of total farm size. This is a crucial point for stakeholders and policymakers to focus on the expansion of the use of scale-appropriate mechanisms for small farmers and also for private sector investors who are looking to provide investment for small-scale farms. Projects like these aim to encourage private-sector-led advancement and business models to promote the acquisition of equipment through local markets. One such example is the M4P project or basic value-chain project with the aim of "creating a market for the poor" (DFID/SDC, 2008). The results of the current study show that small or poor farmers are either less willing or incapable of investing in farming machines and machinery. However, this should not exclude their right or ability to utilize such machines, and development plans need to take into account administrative arrangements and personalized measures for this machinery to be available at affordable prices for small farmers. Previous studies have proved that such efforts would be the primary avenue by which farmers were able to acquire tube wells/irrigation pumps, tillage machinery, tractors, and thrashers within South Asia, including Pakistan (Hossain, 2009; Justice, 2013; Mandal, 2014). Nevertheless, further study of the various dynamics of the service delivery market and its impact on the reception of machinery on the farmers is needed.

Another important finding from this study was the positive relationship between access to credit and machinery ownership among farming households, the relationship was not statistically significant for tillage/other farm implements. Even though Only 53\% households have access to credit services (see table 2). The main reason behind this could be complex documentation required during the banking process. Only a few people in the study had access to credit, and the majority of the farmers relied on middlemen and agents for advanced payment before selling their commodities at a price lower than the market rate to that individual. This often results in a financial crisis for the farmer. Another possible attributing factor to this might be to religiousness of the study population. Majority of the Pakistani farmers are Muslims, and thus they tend to shy away from conventional banking systems to avoid usury and interest. As mentioned in the holy book of the Quran, Surah Al-Imran, verse 130: "O believers! Devour not interest, doubled and redoubled; and fear Allah, in the hope that you may get prosperity". Policy makers need to address this issue carefully through the help of an Islamic banking system. Kaleem and Abdul Wajid (2009) explained the role and process of Islamic banking mechanisms within the agricultural sector. More efforts should be put in to increase the awareness about this issue to encourage the uptake of banking credit services when necessary. The relevant stakeholders need to tackle the problem of documentation complexity and improve accessibility to financial assistance via Islamic banking channel.

In addition, the study also clearly shows the importance of road access in the adoption and utilization of farm machinery. Apart from improved physical connectivity, road access also increases the information flow for farmers and farm workers (Mottaleb, Mohanty, \& Nelson, 2014a).

In terms of sources of energy, electricity was mainly used for irrigation pumps apart from tractors and diesel engines. Water is an essential requirement for agriculture. Due to the severe shortage of electricity, nonscheduled and unpredictable power outages, and the substantial initial investment to install renewable energy 
sources, many farmers still prefer to rely on diesel-engine power. Nevertheless, the results of this study do not reject the impact of other sources of energy on farmers' adoption of farming machinery. It may be argued that other energy sources might have saved on operating costs, thus allowing the farmers to progress towards farm machinery ownership. As Qureshi, Akhtar, and Sarwar (2003) explained, the electricity or renewable sources of energy incurred lower operational costs compared to existing energy sources.

As a result of a rapid decrease in the rural labor force, farmers are also under pressure to invest in machines. Our results suggest that farming households with a greater number of family members available for farm work tend to be less likely in purchasing and owning farming machinery. Farmers can utilize familial labor at a lower cost, without having to rely on outsourced labor that may incur an extra cost. Thus, these farmers do not feel the urgent need to invest capital into farming machinery. Conversely, if a farmer does not have familial help and needs to hire outsourced assistance from non-family, then they would have felt more worthwhile to spend the available capital to invest in machines in order to save time and money (Mottaleb et al., 2016).

\section{CONCLUSION}

Agricultural machinery can assume a crucial role in enhancing and sustaining agricultural growth. A comprehensive insight into the social and economic variables impacting a farmer's capacity to purchase and utilize agrarian machines for food security in South Asia will be highly valuable to guide policymakers in resource planning and budget allocation. Overall, improvement of various necessary infrastructure facilities in Pakistan's rural areas is fundamental to encourage the ownership of agricultural machinery. One of the methods is via renting service of agricultural machinery to small farmers. The provision of credit access as an integral part of mechanization endeavors can ensure sustainable growth of agriculture sector and reduce production risk to farmers. In conclusion, developers and policymakers who hope to boost farming mechanization among farmers in the country should consider upgrading necessities and requirements. Furthermore, it is recommended that small scale and cost-effective farm machinery to be introduced, thereby facilitating the implementation of farm mechanization and increasing the overall efficiency of production in the agricultural sector.

\section{References}

Ahmad, I., Shah, S. A. H., \& Zahid, M. S. (2004). Why the Green Revolution was short run phenomena in the development process of Pakistan: a lesson for future.

Akram, M. W., Akram, N., Hongshu, W., Andleeb, S., Kashif, U., \& Mehmood, A. (2019). Impact of Land Use Rights on the Investment and Efficiency of Organic Farming. Sustainability, 11(24), 7148.

Akram, M. W., Akram, N., Hongshu, W., \& Mehmood, A. (2019). An Assessment of Economic Viability of Organic Farming in Pakistan. CUSTOS E AGRONEGOCIO ON LINE, 15(1), 141-169.

Akram, N., Akram, M. W., Wang, H., \& Mehmood, A. (2019). Does Land Tenure Systems Affect Sustainable Agricultural Development? Sustainability, 11(14), 3925.

Ali, A., Abdulai, A., \& Goetz, R. (2012). Impacts of tenancy arrangements on investment and efficiency: evidence from Pakistan. Agricultural Economics, 43(s1), 85-97.

Amjad, N., Abbas, S. G., Ahmad, T., \& Ali, I. (2014). Agricultural Mechanization Statistical Database Development in Pakistan.

Bochtis, D. D., Sørensen, C. G., \& Busato, P. (2014). Advances in agricultural machinery management: A review. Biosystems engineering, 126, 69-81.

Daberkow, S. G., \& McBride, W. D. (2003). Farm and operator characteristics affecting the awareness and adoption of precision agriculture technologies in the US. Precision Agriculture, 4(2), 163-177.

DFID/SDC. (2008). A Synthesis of the Making Markets Work for the Poor (M4P) Approach.

Farooqui, S. Z. (2014). Prospects of renewables penetration in the energy mix of Pakistan. Renewable and Sustainable Energy Reviews, 29, 693-700.

Hossain, M. (2009). The impact of shallow tubewells and boro rice on food security in Bangladesh (Vol. 917): Intl Food Policy Res Inst.

Iqbal, M. A., Iqbal, A., Afzal, S., Akbar, N., Abbas, R. N., \& Khan, H. Z. (2015). In Pakistan, agricultural 
mechanization status and future prospects. American-Eurasian Journal of Agricultural \& Environmental Sciences, 15(1), 122-128.

Jurriëns, M., Mollinga, P. P., \& Wester, P. (1996). Scarcity by design: protective irrigation in India and Pakistan: ILRI.

Justice, S., Biggs, S. (2013). Rural and agricultural mechanization in Bangladesh and Nepal: status, processes and outcomes. In: Kienzle, J., Ashburner, J.E., Sims, B.G. (Eds.), Mechanization for Rural Development: a Review of Patterns and Progress from Around the World. Food and Agriculture Organization of the United Nations (UNFAO), Rome, pp. 67e98.

Kaleem, A., \& Abdul Wajid, R. (2009). Application of Islamic banking instrument (Bai Salam) for agriculture financing in Pakistan. British Food Journal, 111(3), 275-292.

Kazmi, S., \& Ertsen, M. (2011). Changes in tube wells count in two decades in area under conjunctive irrigation in Pakistan. Paper presented at the Proceedings of the 25th ICID European Regional Conference.

Luqmani, M., \& Quraeshi, Z. (2011). Privatizing state-owned enterprises: a model for developing countries. International Journal of Commerce and Management, 21(3), 256-272.

Mandal, M. (2014). Agricultural mechanization in Bangladesh: role of policies and emerging private sector. Paper presented at the NSD-IFPRI Workshop on "Mechanization and Agricultural Transformation in Asia and Africa: Sharing Development Experiences.

Mariano, M. J., Villano, R., \& Fleming, E. (2012). Factors influencing farmers' adoption of modern rice technologies and good management practices in the Philippines. Agricultural Systems, 110, 41-53.

MOF. (2014-15). Pakistan Economic Survey 2014-15. Islambad: Government of Pakistan, Finance Division, Economic Affairs Wing.

MOF. (2017-18). Pakistan Economic Survey 2017-18. Islambad: Government of Pakistan, Finance Division, Economic Affairs Wing.

MOP. (2017). Long Term Plan for China-Pakistan Economic Corridor (2017-2030). Islamabad: CHINAPAKISTPAN ECONOMIC CORRIDOR.

Mottaleb, K. A., Krupnik, T. J., \& Erenstein, O. (2016). Factors associated with small-scale agricultural machinery adoption in Bangladesh: Census findings. Journal of Rural Studies, 46, 155-168.

Mottaleb, K. A., Mohanty, S., \& Nelson, A. (2014a). Strengthening market linkages of farm households in developing countries. Applied Economic Perspectives and Policy, 37(2), 226-242.

Mottaleb, K. A., Mohanty, S., \& Nelson, A. (2015). Factors influencing hybrid rice adoption: a Bangladesh case. Australian Journal of Agricultural and Resource Economics, 59(2), 258-274.

Mottaleb, K. A., Rahut, D. B., Ali, A., Gérard, B., \& Erenstein, O. (2017). Enhancing smallholder access to agricultural machinery services: lessons from Bangladesh. The journal of development studies, 53(9), 1502-1517.

Paustian, M., \& Theuvsen, L. (2017). Adoption of precision agriculture technologies by German crop farmers. Precision Agriculture, 18(5), 701-716.

Quayum, M. A., \& Ali, A. M. (2012). Adoption and diffusion of power tillers in Bangladesh. Bangladesh Journal of Agricultural Research, 37(2), 307-325.

Qureshi, A. S., Akhtar, M., \& Sarwar, A. (2003). Effect of electricity pricing policies on groundwater management in Pakistan.

Qureshi, A. S., McCornick, P. G., Sarwar, A., \& Sharma, B. R. (2010). Challenges and prospects of sustainable groundwater management in the Indus Basin, Pakistan. Water resources management, 24(8), 1551-1569.

Rahman, S., Hussain, A., \& Taqi, M. (2014). Impact of agricultural credit on agricultural productivity in Pakistan: An empirical analysis. International Journal of Advanced Research in Management and Social Sciences, 3(4), 125-139.

Raza, A. (2018). Pakistan Grain and Feed Annual. In D. William (Ed.), Grain Report: Global Agriculture Information Network. 
Tahir, A., \& Mohamed, A. (2015). Probing agricultural engineering education in Pakistan a changing world. Education, 2(1), 21-28.

Tanveer, S. K., Hussain, I., Sohail, M., Kissana, N., \& Abbas, S. (2003). Effects of different planting methods on yield and yield components of wheat. Asian J. Plant Sci, 2(10), 811-813.

UAF. (2015). MECHANIZATION PACKAGE PUNJAB, PAKISTAN. University of Agriculture Faisalabad.

ur Rehman, T., Khan, M. U., Tayyab, M., Akram, M. W., \& Faheem, M. (2016). Current status and overview of farm mechanization in Pakistan-A review. Agricultural Engineering International: CIGR Journal, 18(2), 83-93.

Younis, M., Sabir, M., Iqbal, M., \& Alit, A. (2006). Comparative performance of zone till sowing, slot planting and conventional sowing technique of wheat in rice-vacated fields. Journal of Agricultural Research, 44(1), 59-70.

GOP (Government of Pakistan), 2010. Agriculture. Ministry of Finance, Government of the Islamic Republic of Pakistan, Islamabad. Available from URL: http://www.finance.gov.pk/survey/chapter_10/02_agriculture.pdf (accessed 11.06.18.). 